\title{
Incidence, trends, and risks of ectopic pregnancy in a population of women
}

\author{
L WESTRÖM, L PH BENGTSSON, P-A MÅRDH
}

\begin{abstract}
In a 20-year longitudinal study on ectopic pregnancy in a defined population of women aged 15-39 years the rate of ectopic pregnancy per 1000 diagnosed conceptions increased from 5.8 during $1960-4$ to $11 \cdot 1$ during 1975-9. The mean annual incidence of ectopic pregnancy per 1000 women increased from 0.6 to 1.2 during the same period. The numbers of ectopic pregnancies per 1000 diagnosed conceptions increased with increasing age of the women and were 4.1 , in the teenage group 6.9 , in women aged 20-29 years, and 12.9 in women aged 30-39. Among 20- to 29-year-old sexually active women at risk of pregnancy who had never had acute salpingitis the rates of ectopic pregnancy per 100 woman-years were the same in those who did not use contraceptives as in those using non-medicated or copper-medicated intrauterine contraceptive devices (IUCDs; $0 \cdot 3 / 100$ woman years). The risk of an ectopic pregnancy increased sevenfold after acute salpingitis.

These findings confirm the increased risk of ectopic pregnancy after salpingitis and suggest that the increase in the incidence of ectopic pregnancy in Lund from 1960 to 1979 was partly accounted for by the use of IUCDs.
\end{abstract}

\section{Introduction}

During the past two decades an increase in the incidence of ectopic pregnancy has been noted in many regions of Europe as well as in the United States (table I). Demographic factors account for part of the numerical increase, but the changes observed in the ratios of ectopic to intrauterine gestations ${ }^{1-5}$ cannot be explained solely by population changes.

In any population the number of ectopic pregnancies is

University Hospital, S-221 85 Lund, Sweden

L WESTRÖM, MD, PHD, associate professor, department of obstetrics and gynaecology

L Ph BENGTSSON, MD, PHD, professor emeritus, department of obstetrics and gynaecology

P-A MARDH, MD, PHD, microbiologist, Institute of Medical Microbiology, University of Lund
TABLE I-Increases in incidence of ectopic pregnancy as reported in different regions

\begin{tabular}{lcc}
\hline Geographical area & Period & $\begin{array}{c}\text { Increase factor } \\
\text { (per 1000 pregnancies) }\end{array}$ \\
\hline Czechoslovakia, Prague $^{1}$ & $1955-66$ & $1 \cdot 7$ \\
England and Wales $^{2}$ & $1 \cdot 6$ \\
Finland, Helsinki $^{4}$ & $1966-76$ & $1 \cdot 9$ \\
Finland, Turku $^{5}$ & $1968-76$ & $1 \cdot 8$ \\
Scotland (unpublished observations) & $1966-75$ & $1 \cdot 7$ \\
Sweden, Lund (see table II) & $1964-74$ & $1 \cdot 9$ \\
Sweden, Uppsala & $1960-79$ & $2 \cdot 5^{*}$ \\
United States? & $1960-75$ & $2 \cdot 7^{*}$ \\
\hline
\end{tabular}

*Absolute increase.

related to the prevalence of fertile women exposed to the chance of a pregnancy and to the distribution of risk factors for ectopic pregnancy among such women. Risk factors include increased age, ${ }^{8}$ postinfection and postoperative tubal damage, ${ }^{910}$ and other tubal lesions. ${ }^{11}$ The immediate effects of such risk factors are often concealed by the use of contraceptives. Furthermore, contraceptive use in itself might influence the epidemiology of ectopic pregnancy. ${ }^{512}$

We report here the numbers of intrauterine and ectopic pregnancies diagnosed during 1960-79 in a defined population of women. We attempted to analyse the interrelations between ectopic pregnancy and the use of intrauterine contraceptive devices (IUCDs) and between ectopic pregnancy and a history of acute salpingitis.

\section{Study population and methods}

Population-The study population lived in the city of Lund in southern Sweden. The city is dominated by public institutions and a university, but lacks major industries. In 1979 the registered population comprised 78678 persons. Our clinic is the only obstetrics and gynaecology clinic in the city and provides all such care for women registered in the city.

Pregnancies-Deliveries were defined according to the International Classification of Diseases (ICD), numbers 650-61. In Lund all deliveries take place in our clinic. In Sweden all legal abortions (ICD 640-2) must be performed in hospitals, and our clinic is the only one performing such operations in Lund. The spontaneous abortions (ICD 643-4, 645.92 , and 645.93 ) were defined as such only when fetal tissues or chorionic villi were identified. In this study we included only tubal 
pregnancies among ectopic pregnancies. The diagnosis was verified by identifying trophoblastic tissue in material removed at laparotomy. Throughout the period of study laparoscopy was used on liberal criteria to verify or exclude an ectopic pregnancy in cases with "classical" symptoms as well as in symptomless cases with a positive pregnancy test result but no demonstrable intrauterine pregnancy.

IUCD use-IUCDs were not used in Sweden before 1965. Up to August 1972 we inserted Lippes's loops C and D as well as Saf-Tcoils. After that we inserted $\mathrm{Cu}-\mathrm{T} 200$ and $\mathrm{Cu}-7200$ devices almost exclusively. Dalkon shields and progesteron-medicated IUCDs were never used. In all women treated for an ectopic pregnancy we recorded the use or non-use of an IUCD. The prevalence as well as womanyears of IUCD use during 1965-9 was evident from an earlier study. ${ }^{13}$ During 1970-4 we studied the use of contraceptives in women aged 20-29 years by sending a questionnaire each month to randomly selected women; the questionnaire asked about contraceptive use in the previous calendar month. The response rate was $82.4 \%$. The results are given in table II. During 1975-9 the mean prevalence of 20- to 29-year-old women using IUCDs was estimated by determining the proportion of women who had become pregnant while using an IUCD in samples of consecutively diagnosed pregnancies. The prevalence was then calculated using the 1975-9 data in table III and in table II a Pearl index of 2.96, which was derived from the 1970-4 series.

Acute salpingitis-Patients who had had salpingitis were those whose records showed a laparoscopically verified acute salpingitis or whose Fallopian tubes at operation for an ectopic pregnancy showed changes that could be attributed to an earlier infection. The incidence of acute salpingitis in Lund as well as the prevalence of women who had had salpingitis have been reported earlier. ${ }^{1415}$ The prevalence of

TABLE II-Use of intrauterine contraceptive devices (IUCDs) in women aged 20-29 years in Lund in 1960-79 and use of other contraceptive methods in same age group in 1970-4

\begin{tabular}{|c|c|c|c|c|c|}
\hline \multirow{2}{*}{ Period } & \multirow{2}{*}{$\begin{array}{c}\text { Contraceptive } \\
\text { method }\end{array}$} & \multirow{2}{*}{$\begin{array}{c}\text { Mean prevalence per } \\
1000 \text { women }\end{array}$} & \multirow{2}{*}{$\begin{array}{c}\text { Sum of } \\
\text { woman- } \\
\text { years }\end{array}$} & \multicolumn{2}{|c|}{ Pregnancies } \\
\hline & & & & Intrauterine & Ectopic \\
\hline \multirow{2}{*}{\multicolumn{2}{|c|}{$\begin{array}{l}1960-4 \text { IUCD } \\
1965-9 \text { IUCD } \\
\text { 1970-4: } \\
\text { IUCD* } \\
\text { Oral contraceptives } \dagger \\
\text { Barrier } \ddagger \\
\text { None: pregnant } \\
\text { None: at risk of pregnancy \& } \\
\text { None: at no risk of pregnancy } \mid \\
\text { 1975-9 IUCD }\end{array}$}} & $\begin{array}{r}0 \\
28\end{array}$ & $\begin{array}{r}0 \\
982\end{array}$ & $\begin{array}{r}0 \\
29\end{array}$ & $\begin{array}{l}0 \\
4\end{array}$ \\
\hline & & $\begin{array}{r}70 \\
389 \\
168 \\
133 \\
120 \\
120 \\
120\end{array}$ & $\begin{array}{r}2940 \\
16311 \\
7044 \\
5577 \\
5032 \\
5033 \\
4740\end{array}$ & $\begin{array}{r}87 \\
49 \\
1036 \\
5318 \\
0 \\
140\end{array}$ & $\begin{array}{r}12 \\
0 \\
6 \\
27 \\
0 \\
20\end{array}$ \\
\hline
\end{tabular}

*During 1970, 71, 72, 73, and 74: 40, 44, 47, 95, and 124 respectively

† Exclusively combined preparations.

†Condoms, diaphragms, local chemicals.

\&Sexually active, including a few using rhythm methods or coitus interruptus.

||Sexually not active plus couples with proved sterility (operated, sterilised, aspermia, etc).

TABLE III-Pregnancies in women aged 15-39 years living in Lund 1960-79

\begin{tabular}{|c|c|c|c|c|c|c|c|c|}
\hline \multirow{2}{*}{$\begin{array}{l}\text { Age group } \\
\text { and period }\end{array}$} & \multirow{2}{*}{$\begin{array}{c}\text { Mean } \\
\text { female } \\
\text { population }\end{array}$} & \multicolumn{3}{|c|}{ Total No of diagnosed pregnancies } & \multirow{2}{*}{$\begin{array}{c}\text { Ectopic pregnancies } \\
\text { per } 1000 \\
\text { diagnosed } \\
\text { conceptions }\end{array}$} & \multirow{2}{*}{\multicolumn{3}{|c|}{$\begin{array}{c}\text { Mean annual rate } \\
\text { of ectopic pregnancy } \\
\text { per } 1000 \\
\text { women }\end{array}$}} \\
\hline & & Intrauterine & Ectopic & & & & & \\
\hline $\begin{array}{r}15-19: \\
1960-4 \\
1965-9\end{array}$ & $\begin{array}{l}2074 \\
2101\end{array}$ & $\begin{array}{l}510 \\
585\end{array}$ & $\left.\begin{array}{l}0 \\
4\end{array}\right\}$ & & $3.6]$ & . & 0.2 & \\
\hline $\begin{array}{l}1970-4 \\
1975-9\end{array}$ & $\begin{array}{l}2108 \\
2169\end{array}$ & $\begin{array}{l}689 \\
647\end{array}$ & $\left.\begin{array}{l}2 \\
4\end{array}\right\}$ & & 4.5 & & 0.3 & \\
\hline $\begin{array}{r}\text { 20-29: } \\
1960-4 \\
1965-9\end{array}$ & $\begin{array}{l}5705 \\
7012\end{array}$ & $\begin{array}{l}3907 \\
5165\end{array}$ & $\begin{array}{l}18 \\
28\end{array}$ & & $\left.\begin{array}{l}4.6 \\
5.4\end{array}\right]$ & & $\begin{array}{l}0.6 \\
0.8\end{array}$ & \\
\hline $\begin{array}{l}1970-4 \\
1975-9\end{array}$ & $\begin{array}{l}8386 \\
7900\end{array}$ & $\begin{array}{l}6490 \\
5529\end{array}$ & $\begin{array}{l}45 \\
54\end{array}$ & & $\left.\begin{array}{l}6.9 \\
9.7\end{array}\right\}^{0.9}$ & & $\begin{array}{l}1 \cdot 1 \\
1 \cdot 4\end{array}$ & \\
\hline $\begin{array}{r}\text { 30-39: } \\
1960-4 \\
1965-9\end{array}$ & $\begin{array}{l}4181 \\
4100\end{array}$ & $\begin{array}{l}1427 \\
1592\end{array}$ & $\begin{array}{l}16 \\
18\end{array}$ & & $\begin{array}{l}11.1 \\
11.2\end{array}$ & & $\begin{array}{l}0.8 \\
0.9\end{array}$ & \\
\hline $\begin{array}{l}1970-4 \\
1975-9\end{array}$ & $\begin{array}{l}4885 \\
6342\end{array}$ & $\begin{array}{l}1900 \\
2381\end{array}$ & $\begin{array}{l}22 \\
38\end{array}$ & & $\left.\begin{array}{l}11.5 \\
15.7\end{array}\right\}^{12.9}$ & & $\begin{array}{l}0.9 \\
1.2\end{array}$ & \\
\hline $\begin{array}{l}\text { Total: } \\
1960-4 \\
1965-9\end{array}$ & $\begin{array}{l}11960 \\
13213\end{array}$ & $\begin{array}{l}5844 \\
7342\end{array}$ & $\begin{array}{l}34 \\
50\end{array}$ & & $\left.\begin{array}{l}5 \cdot 8 \\
6.8\end{array}\right]$ & & $\begin{array}{l}0.6 \\
0.8\end{array}$ & \\
\hline $\begin{array}{l}1970-4 \\
1975-9\end{array}$ & $\begin{array}{l}15379 \\
16411\end{array}$ & $\begin{array}{l}9079 \\
8557\end{array}$ & $\begin{array}{l}69 \\
96\end{array}$ & & $\left.\begin{array}{r}7 \cdot 5 \\
11 \cdot 1\end{array}\right\}^{8 \cdot 1}$ & & $\begin{array}{l}0.9 \\
1.2\end{array}$ & \\
\hline
\end{tabular}

TABLE IV-Rates of ectopic pregnancy per 100 women-years of IUCD use in women aged 2029 years in Lund in 1960-79

\begin{tabular}{|c|c|c|c|c|c|}
\hline & $1960-4$ & $1965-9$ & $1970-4$ & $1975-9$ & Total \\
\hline $\begin{array}{l}\text { All IUCD users: } \\
\text { Sum of woman-years } \\
\text { No of ectopic pregnancies } \\
\text { Ectopic pregnancies/100 woman-years }\end{array}$ & $\begin{array}{l}0 \\
0 \\
0\end{array}$ & $\begin{array}{c}982 \\
4 \\
0.4\end{array}$ & $\begin{array}{c}2940 \\
12 \\
0.4\end{array}$ & $\begin{array}{c}4740 \\
20 \\
0.4\end{array}$ & $\begin{array}{r}8622 \\
36 \\
0.4\end{array}$ \\
\hline $\begin{array}{l}\text { IUCD users who had had salpingitis: } \\
\text { Sum of woman-years } \\
\text { No of ectopic pregnancies } \\
\text { Ectopic pregnancies/100 woman-years }\end{array}$ & $\begin{array}{l}0 \\
0 \\
0\end{array}$ & $\begin{array}{r}100 \\
2\end{array}$ & $\begin{array}{r}295 \\
3\end{array}$ & $\begin{array}{r}285 \\
4\end{array}$ & $\begin{array}{c}680 \\
9 \\
1 \cdot 3\end{array}$ \\
\hline $\begin{array}{l}\text { IUCD users who had not had salpingitis: } \\
\text { Sum of woman years } \\
\text { No of ectopic pregnancies } \\
\text { Ectopic pregnancies/100 woman-years }\end{array}$ & $\begin{array}{l}\mathbf{0} \\
\mathbf{0} \\
\mathbf{0}\end{array}$ & $\begin{array}{c}882 \\
2 \\
0 \cdot 2\end{array}$ & $\begin{array}{r}2645 \\
9 \\
0.3\end{array}$ & $\begin{array}{c}4455 \\
16 \\
0.4\end{array}$ & $\begin{array}{r}7942 \\
27 \\
0.3\end{array}$ \\
\hline
\end{tabular}


women who had had salpingitis and were using IUCDs was determined from our continuous follow-up studies of women who had had laparoscopically acute salpingitis ${ }^{16}$ (and unpublished observations).

\section{Results}

During 1960-79 30822 intrauterine and 249 ectopic pregnancies were diagnosed in women aged 15-39 years living in Lund (table III).

Throughout the period of study the rate of ectopic pregnancy per 1000 diagnosed conceptions increased with the increasing age of the women. The figures were: $4 \cdot 1$ for the teenage group, $6 \cdot 9$ for those
The analyses of the interrelations between ectopic pregnancy, IUCD use, and postsalpingitic tubal damage were confined to women aged 20-29 years because the information on IUCD use in the other age groups was less reliable.

IUCD use and ectopic pregnancy-In women aged 20-29 years the total ectopic pregnancy rate per 100 woman-years of IUCD use was 0.4 . Among those who had suffered salpingitis the rate was 1.3 and among those who had not it was 0.3 (table IV).

From the information in tables II and III we calculated that if the 20-29 year olds who used IUCDs had used oral contraceptives instead the increase from 4.6 to 9.7 in ectopic pregnancy rate per 1000 conceptions from 1960 to 1979 (table III) would have stopped at 5.0.

Salpingitis and ectopic pregnancy-Of the 254 ectopic pregnancies

\begin{tabular}{|c|c|c|c|c|c|c|c|c|c|c|c|}
\hline \multirow{2}{*}{ Period } & \multicolumn{5}{|c|}{ Women not using IUCDs } & \multicolumn{5}{|c|}{ Women using IUCDs } & \multirow{2}{*}{ Total } \\
\hline & $15-19$ & $20-29$ & $30-39$ & $>39$ & Total & $15-19$ & $20-29$ & $30-39$ & $>39$ & Total & \\
\hline $\begin{array}{l}1960-4 \\
1965-9 \\
1970-4 \\
1975-9\end{array}$ & $\begin{array}{l}0 \\
4 \\
1 \\
2\end{array}$ & $\begin{array}{l}18 \\
24 \\
33^{*} \\
34\end{array}$ & $\begin{array}{l}16 \\
15 \\
16 \\
19\end{array}$ & $\begin{array}{l}1 \\
1 \\
1 \\
2\end{array}$ & $\begin{array}{l}A l \\
35 \\
44 \\
51 \\
57\end{array}$ & $\begin{array}{r}\text { men } \\
0 \\
0 \\
1 \\
2\end{array}$ & $\begin{array}{r}0 \\
4 \\
12 \\
20\end{array}$ & $\begin{array}{r}0 \\
3 \\
6 \\
19\end{array}$ & $\begin{array}{l}0 \\
0 \\
0 \\
0\end{array}$ & $\begin{array}{r}0 \\
7 \\
19 \\
41\end{array}$ & $\begin{array}{l}35 \\
51 \\
70 \\
98\end{array}$ \\
\hline Total & & & & & 187 & & & & & 67 & 254 \\
\hline $\begin{array}{l}1960-4 \\
1965-9 \\
1970-4 \\
1975-9\end{array}$ & $\begin{array}{l}0 \\
2 \\
1 \\
1\end{array}$ & $\begin{array}{l}8 \\
12 \\
17 \dagger \\
16\end{array}$ & $\begin{array}{r}8 \\
9 \\
13 \\
11\end{array}$ & $\begin{array}{l}\text { Wor } \\
1 \\
0 \\
1 \\
2\end{array}$ & $\begin{array}{c}\text { who hac } \\
17 \\
23 \\
32 \\
30\end{array}$ & $\begin{array}{c}d \text { acute } \\
0 \\
0 \\
0 \\
1\end{array}$ & $\begin{array}{c}\text { ingitis } \\
0 \\
2 \\
3 \\
4\end{array}$ & $\begin{array}{l}0 \\
1 \\
0 \\
2\end{array}$ & $\begin{array}{l}\mathbf{0} \\
\mathbf{0} \\
\mathbf{0} \\
\mathbf{0}\end{array}$ & $\begin{array}{l}0 \\
3 \\
3 \\
7\end{array}$ & $\begin{array}{l}17 \\
26 \\
35 \\
37\end{array}$ \\
\hline Total & & & & & 102 & & & & & 13 & 115 \\
\hline
\end{tabular}

*Twelve did not use contraceptives and had never had salpingitis.

+Fifteen did not use contraceptives.

TABLE VI-Calculated rates of ectopic pregnancy per 100 woman years in sexually active women aged 20-29 years not using contraceptives and at risk of pregnancy with and without history of previous acute salpingitis (see text)

\begin{tabular}{lcccccc}
\hline & \multicolumn{3}{c}{ Ectopic pregnancies per 100 woman-years during: } & \multirow{2}{*}{ Total } \\
\cline { 2 - 6 } & $1960-4$ & $1965-9$ & $1970-4$ & $1975-9$ & \\
\hline $\begin{array}{llllll}\text { Women who had had salpingitis } \\
\text { Women who had not had salpingitis }\end{array}$ & 2.3 & 1.9 & 1.9 & 1.9 & 1.9 \\
\hline
\end{tabular}

TABLE VII-Reproductive events after acute salpingitis in women who exposed themselves to risk of pregnancy ${ }^{16}$

\begin{tabular}{|c|c|c|c|c|c|}
\hline \multirow{2}{*}{$\begin{array}{l}\text { No of episodes of infection } \\
\text { and age group }\end{array}$} & \multicolumn{2}{|c|}{ Pregnant } & \multicolumn{2}{|c|}{ Involuntarily not pregnant ${ }^{*}$} & \multirow{2}{*}{ Tota } \\
\hline & Intrauterine & Ectopic & Tubal occlusion & Other causes & \\
\hline $\begin{array}{l}\text { One episode: } \\
15-19 \\
20-24 \\
25-34\end{array}$ & $\begin{array}{r}176 \\
192 \\
75\end{array}$ & $\begin{array}{r}6 \\
10 \\
9\end{array}$ & $\begin{array}{l}18 \\
22 \\
20\end{array}$ & $\begin{array}{r}7 \\
14 \\
12\end{array}$ & $\begin{array}{l}207 \\
238 \\
116\end{array}$ \\
\hline $\begin{array}{l}\text { Two episodes: } \\
15-19 \\
20-24 \\
25-34\end{array}$ & $\begin{array}{l}36 \\
38 \\
19\end{array}$ & $\begin{array}{l}3 \\
6 \\
1\end{array}$ & $\begin{array}{r}12 \\
10 \\
9\end{array}$ & $\begin{array}{l}2 \\
0 \\
0\end{array}$ & $\begin{array}{l}53 \\
54 \\
29\end{array}$ \\
\hline $\begin{array}{l}\text { Three or more episodes } \\
15-19 \\
20-24 \\
25-34\end{array}$ & $\begin{array}{l}7 \\
5 \\
6\end{array}$ & $\begin{array}{l}1 \\
2 \\
0\end{array}$ & $\begin{array}{r}10 \\
8 \\
9\end{array}$ & $\begin{array}{l}0 \\
0 \\
0\end{array}$ & $\begin{array}{l}18 \\
18 \\
15\end{array}$ \\
\hline Total & 554 & 38 & 118 & 35 & $745^{*}$ \\
\hline
\end{tabular}

* 155 voluntarily not pregnant women were excluded.

aged 20-29, and 12.9 for those aged 30-39. From 1960-4 to 1975-9, the total rate of ectopic pregnancy per 1000 diagnosed conceptions increased from $5 \cdot 8$ to $11 \cdot 1$ (table III). The mean annual incidence of ectopic pregnancy per 1000 women aged 15-39 years increased from 0.6 in 1960-4 to 1.2 in 1975-9. The increase was most pronounced in women aged 20-29. From 1970 onwards the mean annual incidence of ectopic pregnancy per 1000 women in this age group became higher than in women aged 30-39 (table III). studied (including five in women aged over 39) $115(45.3 \%)$ were in women who had suffered acute salpingitis. In women aged 20-29 the corresponding figure was $42.8 \%$ (table $\mathrm{V}$ ). In the total population of women aged 20-29 years the mean prevalences of women who had had salpingitis were: $1960-4 \quad 9.8 \% ; 1965-912.9 \%, 1970-414.9 \%$ and $1975-915.9 \%^{15}$ In the $1970-4$ questionnaire study (table II) we identified 1006 women aged 20-29 years who were sexually active and at risk of pregnancy because they did not use any contraception. This 
group of women contributed a total of 5318 intrauterine and 27 ectopic pregnancies during 5032 woman years. The mean proportion of women in this group who had suffered salpingitis was $15.2 \%$, corresponding to a mean prevalence of 154 post-salpingitic women and 852 women who had never had acute salpingitis and who contributed 15 and 12 ectopic pregnancies respectively. There were 1.9 ectopic pregnancies per 100 woman-years of exposure to pregnancy without contraception among women who had had salpingitis and 0.3 in those with no history of salpingitis.

Assuming that the size of the groups of women not using contraceptives who were at risk of a pregnancy was proportional to the numbers of pregnancies diagnosed in those groups, and that the rates of pregnancies in women using other methods of contraception than IUCDs were the same as in 1970-4, we used the information in tables II-V to estimate the size of the groups of sexually active women not using contraception and at risk of pregnancy-and hence the ectopic pregnancy rates-in 1960-4, 1965-9, and 1975-9 (table VI).

\section{Discussion}

We believe that, apart from spontaneous abortions in women who never consulted the doctors at our clinic and all illegal abortions, almost all pregnancies in the city of Lund during 1960-79 were studied. Our study showed that the incidence of ectopic pregnancy rose from 5.8 per 1000 conceptions in 1960-4 to 11.1 in $1975-9$. The incidence also rose with increasing age, from 4.1 in teenagers to 12.9 in 30 to 39 year olds. Both these increases have been noted by other workers ${ }^{8}$ (table I).

In $1977 \mathrm{Sivin}^{7}$ reported 40700 ectopic pregnancies among the 49110000 women aged $15-44$ years in the USA-a rate of 0.83 ectopic pregnancies per 1000 women. When the roughly 3500 women aged 40-44 years in Lund were added to our 1975-9 series we arrived at 98 ectopic pregnancies (table V) in 19900 women-an annual rate of 0.98 per 1000 women aged 15-44. The age group 20-29 dominates the female population in Lund, and sterilisations and hysterectomies are less common in Sweden than in the USA.

In England and Wales in $1976 \mathrm{Beral}^{2}$ estimated that about 3500 hospital discharges were due to ectopic pregnancy. If we apply the US figure of 0.83 ectopic pregnancies per 1000 women, or our 1975-9 age-specific incidence rates (table III), to the 10020000 women aged 15-44 years in England and Wales in 1978 , we arrive at a total of 8350 to 9400 ectopic pregnancies during that year. The discrepancy between those calculated figures and Beral's estimate probably reflects differences in reporting and diagnostic systems, but might also depend on true regional differences.

The relatively high ectopic pregnancy rate in Lund could be explained by the high proportion of women in the peak fecundity age group of 20-29 years. Our liberal use of laparoscopy may also have discovered some ectopic pregnancies that would otherwise have eventually healed spontaneously. The proportion of such pregnancies is unknown, but our results suggest that spontaneously healing ectopic pregnancies might not be unusual.

The incidence of ectopic pregnancy in women using IUCDs in this series was about three times higher than that reported by Tietze $^{17}$ for non-medicated IUCDs (0.09) and by Sivin ${ }^{7}$ for copper-medicated devices (0.09) and four times higher than the rate reported by Vessey $(0 \cdot 07) .{ }^{18}$ The different results may not, however, be inconsistent. Firstly, our data were restricted to the age group with the highest conception rate-also among IUCD users ${ }^{17}{ }^{18}$ - whereas the studies cited included IUCD users aged 15-44 years. Secondly, the estimates presented by others ${ }^{7818}$ were based on prospective cohort studies; ours was a population study. Thirdly, we adopted aggressive diagnostic methods for excluding ectopic pregnancies, even in patients in cases with few symptoms.

In a prospective study on the reproductive events in 900 women aged 15-34 who had had laparoscopically verified acute salpingitis ${ }^{16} 38$ out of 544 first pregnancies were ectopic (table VII)-a rate of 68.8 per 1000 conceptions. The risk of the first pregnancy after acute salpingitis being an ectopic pregnancy increased both with the number of infections and the age of the women at the time of the infection. Women whose first pregnancy after salpingitis was intrauterine less often had an ectopic pregnancy later. Therefore, the rate of ectopic pregnancy per 1000 diagnosed conceptions in all pregnancies after acute salpingitis was $41 \cdot 6 .^{19}$ In a control group of women who had never had salpingitis 1 out of 148 conceptions were ectopic. ${ }^{19}$ The figure is difficult to evaluate because of the single ectopic pregnancy but indicates, like the figures in table VI, a sixfold to sevenfold increase in the risk of an ectopic pregnancy after acute salpingitis.

Our data and calculations therefore suggest the following conclusions. Firstly the incidence of ectopic pregnancy among sexually active women who have never had salpingitis is the same in women not using contraceptives as in those using nonmedicated or copper-medicated IUCDs. Secondly, the risk of an ectopic pregnancy increases about sevenfold after acute salpingitis. Thirdly, the rate of ectopic pregnancy has doubled in Lund during the last two decades, and-at least among women aged 20-29 years-the use of IUCDs seems to account for a substantial proportion of this increase. Although derived from a small population of women, our data agree with the conclusions and observations of others. Thus Urquhart ${ }^{12}$ calculated an index of 0.27 ectopic pregnancies per 100 woman-years of non-contraceptive use in women who had not had acute salpingitis and 2.7 in those who had had salpingitis-a tenfold increase in risk. In 1979 Sivin $^{7}$ stated that "... extrauterine gestation rates associated with IUD devices are not clearly different from those associated with non-use of contraceptives or use of traditional methods."

\section{References}

1 Cernoch VA. Künstliche Schwangerschaftsunterbrechung und extrauterine Schwangerschaft. Zentralbl Gynäkol 1971;93:1784-91.

2 Beral V. An epidemiological study of recent trends in ectopic pregnancy. Brf Obstet Gynaecol 1975;82:775-82.

3 Robinson N, Beral V. Risk of ectopic pregnancy. Lancet 1979 ;ii:1247-8.

4 Savolainen E, Saksela E. Ectopic pregnancy. Relationship to preceeding contraception. Ann Chir Gynaecol 1978;67:198-202.

5 Erkkola R, Liukko P. Intrauterine device and ectopic pregnancy. Contraception 1977;16:569-74.

6 Meirik O, Berg AA, Nillius SJ, Nygren K-G, Reinius S. Utomkvedshavandeskap, spiraler, och lågdosgestagener. Hygiea (Stockholm) 1979; $86: 151$.

7 Sivin L. Copper-T IUD use and ectopic pregnancy rates in the United States. Contraception 1979;19:151-73.

8 Tatum HJ, Schmidt P. Contraceptive and sterilization practices and extrauterine pregnancy: A realistic perspective. Fertil Steril 1977;24: 407-21.

- Siegler AM. Surgical treatment for tuboperitoneal causes of infertility since 1967. Fertil Steril 1977;28:1019-24.

${ }^{10}$ Hasselhorst G. Die ektopische Schwangerschaft. In: Seitz L, Amreich AL, eds. Biologie und Pathologie des Weibes. Vol IX. Berlin: Urban and Schwarzenberg, 1963:631-40.

11 Persault V. Etiology of tubal pregnancy. Radiologic and pathologic studies. Obstet Gynecol $1970 ; 36: 257-65$.

12 Urquhart J. Effect of the venereal disease epidemic on the incidence of ectopic pregnancy-implications for the evaluation of contraceptives. Contraception 1979;19:455-80.

13 Weström L. Intrauterine preventivmedel-biverkningar och kvinnornas värdering i 1100 fall. Läkartidningen (Stockholm) 1972;69:4131-35.

14 Weström L, Mårdh P-A. Pelvic inflammatory disease. I. Epidemiology, diagnosis, clinical manifestations, and sequelae. Geneva: WHO (in press). (Technical Report Series.)

15 Weström L. Incidence, prevalence, and trends of pelvic inflammatory disease and its consequences in industrialised countries. Amer $\mathcal{F}$ Obstet Gynecol (in press).

${ }^{16}$ Weström L, Mårdh P-A. Impact of sexually transmitted diseases on human reproduction. Swedish Studies on Infertility and Ectopic Pregnancy. Washington, DC: NIH NIAID/STD study group (in press).

${ }^{17}$ Tietze C, Lewitt S. Evaluation of intrauterine devices: Ninth progress report of the cooperative statistical program. Studies in Family Planning 1970; No 5:1-40.

18 Vessey MP, Yeates D, Flavel R. Risk of ectopic pregnancy and duration of use of an intrauterine device. Lancet 1979 ;ii-501-2.

19 Weström L. Effect of pelvic inflammatory disease on fertility. Amer 7 Obstet Gynecol 1975;121:707-13.

(Accepted 23 October 1980) 